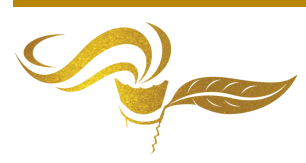

\title{
The COVID-19 pandemic in Brazil: what is happening on the front line
}

\author{
Alex Isidoro Ferreira Prado ${ }^{1}$, Ana Karolina Barreto Berselli Marinho ${ }^{2}$, Cristiane \\ Chaves Gattaz ${ }^{2 *}$, Wesley Mendes-Da-Silva ${ }^{3}$ \\ 1 Hospital das Clínicas Medical School at University of Sao Paulo - USP, Brazil \\ 2 Immunity Initiative, Brazil, (www.immunityinitiative.com.br) \\ 3 Sao Paulo School of Business Administration - FGV/EAESP, \\ (https://eaesp.fgv.br/professor/wesley-mendes-silva) \\ * Correspondence: Email:cristiane.gattaz@gmail.com
}

Received 27 November, 2020; Revised 5 January, 2021; Accepted January 8, 2021

Available online 12 January, 2021 at www.atlas-journal.org, doi: 10.22545/2021/00146

\section{Short Letter}

Knowledge about a disease, regardless of its etiology, passes through several spheres and the impact on health is known to be only the most obvious. The pandemic COVID-19, a disease caused by the SARS-CoV2 virus, has proved the resilience of communities around the world, especially in countries underprepared in terms of a variety of aspects such as infrastructure, technology and education. One of the largest economies in the world, Brazil as an emerging country has faced this great challenge. The number of deaths and the economic damage resulting from the pandemic are explicitly worthy of attention by the government, industry and academia.

This pandemic proved to Brazil and worldwide how much repercussion a bankruptcy in the health system can bring - there is no perfect health management when it comes to a disease that can also affect those who are not infected by it: the need for confinement and a change in habit has led to food shortages, unemployment and mental disorders. The speed, the way of conveying information and the advent of so-called fake news have increased cases of stress and anxiety about the disease and its consequences. The isolation imposed by the disease was once called Van Hoof's "greatest psychological experiment in the world" (Lima, 2020) [1].

There is an estimate that the psychological impairment generated by COVID-19 is between one third and half of the population if they do not receive adequate care. Obviously, the number of people psychologically affected by the pandemic is greater than the number of people infected by the virus itself. Health professionals and related areas such as drivers, cleaning staff and hospital administration are also classified as groups at mental risk due to the constant fear of infection and death.

Unfortunately, despite a pandemic of fear and stress within that generated by the coronavirus, it still lacks numbers that can assess specific population groups. Some measures have been taken in order to 
minimize or treat such conditions - some societies such as Universities of psychoanalysis have set up online service groups to serve the general population. The Brazilian Ministry of Health announced the creation of a program that offers support with teleconsultations for frontline professionals in combating the epidemic. The regional nursing council of Sao Paulo provided a chat to assist and support the professionals' mental health. Such tools prove to be useful to minimize the damage caused to health professionals who are at the forefront in this pandemic (Angelo et al., 2020 [2]; Duarte et al., 2020 [3]).

The pandemic also brought political instability and polarization between parties, discussions about treatment and the lack of scientific support: in a short time Brazil made two exchanges of Ministers of Health with divergent opinions and coping strategies leading to a discontent of society by the lack clarity of information about the pandemic and future prospects (Angelo et al., 2020 [2]).

The economic change generated by COVID-19 was abrupt and brought discouraging numbers. Current economic estimates point, for example, to a drop in GDP in 2020 to $7.7 \%$ - in confirmation of this figure, it will be the worst economic recession in the country's history. Currently, the accumulated devaluation of the Brazilian currency is $45 \%$. In April this year, the application for unemployment insurance was $39 \%$. Unemployment reaches a rate of $12.8 \%$ with a catastrophic number of 12 million unemployed. Another data that speaks in favor of the recession is the shrinkage of industrial production, which varied between the states, showing a total value of the country of $9.1 \%$ in the month of March.

There is still no data to assess the environmental changes generated by the pandemic in Brazil, however globally we know that despite the discreet reduction in $\mathrm{CO}_{2}$ emission rates, oil companies seek incentives from governments to maintain their production in order to minimize economic impacts and they may negatively compensate for the pollution rates once reduced at the beginning of the pandemic (Revista Exame, 2020 [4]).

In spite of all the changes and negative impacts caused by the pandemic in Brazil, we must consider some positive impacts in the health area, such as: greater investment in clinical research, especially related to the development of vaccines, drugs and diagnostic methods, as well as the development of technologies without health as implantation of telemedicine in much of the country. We are still a long way from achieving control of the current situation, but we hope that greater integration between the different spheres of society, both the public and private sectors, can result in solutions that help to face high impact events such as the pandemic.

\section{References}

[1] Lima, Rossano Cabral. (2020). Distanciamento e isolamento sociais pela Covid-19 no Brasil: impactos na saúde mental. Physis: Revista de Saúde Coletiva, 30(2), e300214. Epub July 24, 2020.https://doi.org/10.1590/s010373312020300214

[2] Angelo, Jussara Rafael, Leandro, Bianca Borges da Silva \& Perissé, André Reynaldo Santos. (2020). Fiocruz. $2^{\circ}$ Boletim Epidemiológico da COVID-19 nas favelas. https://portal.fiocruz.br/sites/portal.fiocruz.br/

[3] Duarte, Michael de Quadros, Santo, Manuela Almeida da Silva, Lima, Carolina Palmeiro, Giordani, Jaqueline Portella, \& Trentini, Clarissa Marceli. (2020). COVID-19 e os impactos na saúde mental: uma amostra do Rio Grande do Sul, Brasil. Ciência \& Saúde Coletiva, 25(9), 3401-3411. Epub August 28, 2020.https://doi.org/10.1590/1413-81232020259.16472020

[4] REVISTA EXAME. (2020). 6 números mostram o dramático impacto do coronavírus na economia. May 16th, 2020. Accessed: Nov 10th, 2020. Link: https://exame.com/economia/6-numeros-mostram-o-dramaticoimpacto-do-coronavirus-na-economia/

Funding: This short letter received no external funding.

Conflicts of Interest: The authors declares no conflict of interest. 


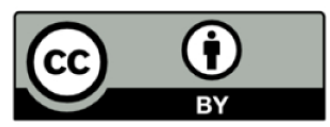

Copyright (C) 2021 by the authors. This is an open access article distributed under the Creative Commons Attribution License (https://creativecommons.org/licenses/by/4.0/), which permits unrestricted use, distribution, and reproduction in any medium, provided the original work is properly cited.

\section{About the Authors}

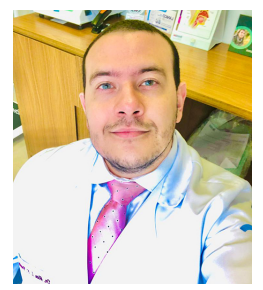

Alex Isidoro Ferreira Prado is a resident doctor in the Clinical Immunology and Allergy Service at the Hospital das Clínicas, Faculdade de Medicina da USP. Doctor of the rare and immunological diseases team at Hospital 9 de Julho in São Paulo. Specialist in Internal Medicine at Hospital das Clínicas, Medical School, University of São Paulo and Graduated in Medicine from the Federal University of Santa Catarina.

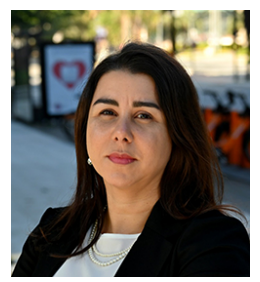

Dr. Ana Karolina Barreto Berselli Marinho graduated in Medicine at the Santa Casa de Misericórdia de Vitória School of Medicine (2001) and Medical Residency in Internal Medicine and Allergy and Clinical Immunology. Master and PhD in Sciences from the Faculty of Medicine of the University of São Paulo (2013) (2019). Coordinator of the Immunization Advisory Group of the Brazilian Association of Allergy and Immunopathology (ASBAIBiennium 2019-2020). She coordinates the Vaccine Adverse Events outpatient clinic at the Clinical Immunology and Allergy Service of Hospital das Clínicas, FMUSP. Professor in the Medicine Course at Nove de Julho University. Supervisor of the Medical Clinic Residency Program at Conjunto Hospitalar do Mandaqui. The experience in the area of Immunology and the pioneering spirit in the study of Vaccines and Allergies in Brazil resulted in participation as a speaker and advice in national and international events in the areas of health and education. She is a member of several scientific societies such as the Brazilian Society of Immunology (SBI), Brazilian Society of Immunizations (SBIm), American Academy of Asthma, Allergy and Immunology (AAAAI) and European Society of Allergy and Immunology (EEACI).

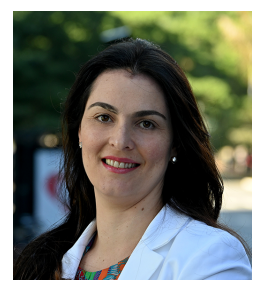

Dr. Cristiane Chaves Gattaz is an associate Researcher at the University of Texas at Austin, working at the Moody College of Communication and the $\mathrm{IC}^{2}$ Institute, where she obtained her master's degree in Science \& Technology Commercialization (2002) and was Visiting Scholar (2018). PhD in Production Engineering from POLI / USP (2010), a post-doctorate from Embrapa Instrumentação (2015), Member of the Board and Research Fellow 
of the Society for Design and Process Science (SDPS) / Software Engineering Society (SES) and Associate Member of the Academy of Management (AOM), IEEE, ANPAD and ABEPRO. Supervises the impact of governance, organizational communication and technology in public and private environments on increasing corporate leadership using transdisciplinary approach. Observes the strategic management aspects of the transfer, commercialization, adoption and socialization of the innovation results of individuals, teams and communities, involved in entrepreneurial ecosystems. In partnership with Top 10 Schools of Engineering, Art and Design in the world such as University of California, University of Texas, Dell Medical School, University of Tromso, Norway, her performance in teaching, research and extension in the field has resulted in the annual organization of international technical-scientific events, in 10 software registered patents, articles, book and book chapters, media, funded projects, guidelines, technological products, titles and awards, nationally and internationally. She is also a referee and associate editor of international impact journals.

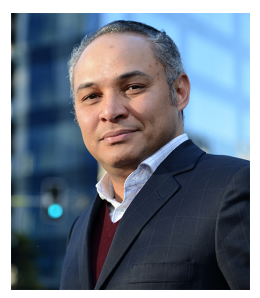

Dr. Wesley Mendes-Da-Silva is one of the founders of the Brazilian Society of Finance, obtained his Habilitation in Finance in 2015 and a PhD in Business Administration, both from the University of Sao Paulo (Brazil). He is a Research Affiliate of the University of Illinois Center for Economic and Financial Education, and the Department of Electrical Engineering \& Computer Science/University of California at Irvine. He was a Visiting professor of Corporate Finance at the BYU Marriott School of Business (2014-2015), and University of Texas at Austin (2017-2018). Wesley is a teacher, researcher, and Masters and PhD advisor in Finance from FGV / EAESP. He has published papers and received awards (in the academic and business media) in Brazil and abroad, focusing on the capital and corporate finance market. He is a technical advisor of Research Support Agencies in Brazil and abroad, e.g. the State of Sãão Paulo (FAPESP) and The Social Sciences and Humanities Research Council of Canada (SSHRC). He is co-author of books, Associate Editor and Referee of impact journals such as: Emerging Markets Review, Encyclopedia with Semantic Computing, Journal of Business Ethics, Journal of Happiness Studies, Scientometrics, Journal of Economic Psychology, Journal of Cleaner Production, Energy (Oxford), and Journal of Management and Governance. He also holds the title of 1st Lieutenant in the Brazilian Army. 